Jurnal J-Ensitec: Vol 02|No. 01, November 2015

\title{
KAJIAN TERHADAP PRODUKTIVITAS DENGAN MEMPERTIMBANGKAN ASPEK KESELAMATAN DAN KESEHATAN KERJA KARYAWAN PADA KAWASAN INDUSTRI PERHOTELAN SANGKANHURIP KABUPATEN KUNINGAN
}

\author{
Otong Karyono \\ Teknik Industri Fakultas Teknik Universitas Majalengka \\ ER Ummi Kalsum, \\ Ummikalsum237@yahoo.co.id
}

\begin{abstract}
Abstrak
Produktivitas menjadi salah satu faktor yang perlu dipertimbangkan oleh setiap perusahaan baik jasa maupun manufaktur. Produktivitas sangat penting untuk meningkatkan keunggulan perusahaan, semakin meningkatkan produktivitas maka akan memberikan dampak positif terhadap peningkatan profitabilitas yang didapat oleh perusahaan. Banyak faktor yang dapat mempengaruhi produktivitas, di antaranya adalah faktor keselamatan dan kesehatan kerja. Faktor keselamatan dan kesehatan kerja merupakan merupakan dua faktor yang sangat berkaitan untuk menjaga stabilitas kerja karyawan.Semakin baiknya program keselamatan dan kesehatan kerja maka semakin baik pula tingkat produktivitas kerja seorang karyawan.
\end{abstract}

Kata kunci: Industri, Keselamatan, Produktifitas, Profitbilitas,

\section{PENDAHULUAN}

Semakin ketatnya persaingan di bidang industri menuntut perusahaan harus mampu bertahan dan berkompetisi.Salah satu hal yang dapat ditempuh perusahaan agar mampu bertahan dalam persaingan yang ketat yaitu dengan meningkatnya produktivitas kerja.Produktivitas pada dasarnya merupakan suatu sikap mental yang selalu mempunyai pandangan bahwa mutu kehidupan hari ini harus lebih baik dari hari kemarin dan hari esok harus lebih baik dari hari ini.Produktivitas mengandung pengertian perbandingan antara hasil yang dicapai dengan keseluruhan sumber daya yang dipergunakan. Faktor-faktor yang mempengaruhi tingkat produktivitas diantaranya adalah pendidikan dan latihan ketrampilan, gizi/nutrisi, kesehatan, bakat atau bawaan, motivasi atau kemauan, kesempatan kerja, kesempatan manajemen dan kebijakan pemerintah (Soeprihanto, 1996:153).

Salah satu faktor yang mempengaruhi produktivitaskerja adalah kesehatan kerja, Perusahaan perlu memelihara kesehatan para karyawan, kesehatan ini menyangkut kesehatan fisik ataupun mental. Kesehatan para karyawan yang buruk akan mengakibatkan kecenderungan tingkat absensi yang tinggi dan produktivitas yang rendah. Adanya program kesehatan yangbaik akan menguntungkan para karyawan secara material, karenamereka akan lebih jarang absen bekerja dengan lingkungan yang menyenangkan, sehingga secara keseluruhan akan mampu bekerja lebih lama berarti lebih produktif.Program kesehatan kerja dapat dilakukan dengan penciptaan lingkungan kerja yang sehat.Hal ini menjaga kesehatan dari gangguan-gangguan penglihatan, pendengaran, kelelahan dll. Penciptaanlingkungan kerja yang sehat secara tidak langsung akan mempertahankan atau bahkan meningkatkan produktivitas (Tulus, 1992:159). Program kesehatan kerja tidak terlepas dari program keselamatan kerja, karena dua program tersebut tercakup dalam pemeliharaan terhadap karyawan. Keselamatan kerja merupakan keselamatan yang bertalian dengan mesin, pesawat, alat kerja, bahan dan proses pengolahannya, landasan tempat kerja dan lingkungannya serta cara-cara melakukan pekerjaan. Keselamatan kerja bersasaran segala tempat kerja , baik didarat, didalam tanah, dipermukaan air, didalam air, 
maupun diudara. "Keselamatan kerja merupakan sarana untuk pencegahan kecelakaan, cacat, dan kematian sebagai akibat kecelakaan kerja" (Suma'mur, 1993:1). Penyebab kecelakaan kerja ada empat faktor diantaranya: faktor nasib dari para karyawan, Faktor lingkungan fisik pada karyawan, seperti mesin, gedung, ruangan, peralatan. Faktor kelalaian manusia dan faktor ketidakserasian kombinasi faktor-faktor produksi yang dikelola dalam perusahaan (Soeprihanto, 1996:47).Dapat diambil suatu contoh data kecelakaan yang pernah terjadi di Indonesia dengan berbagai kasusnya.

Tabel 1. Jumlah Kecelakaan Kerja Tahun 20102011

\begin{tabular}{|c|l|c|c|c|}
\hline No. & Kecelakaan Kerja & Tahun 2000 & Tahun 2001 & $\begin{array}{c}\text { Tahun } \\
\mathbf{2 0 0 2}\end{array}$ \\
\hline 1. & Jumlah Kasus & 17,259 & 309 & \\
2. & Jumlah Korban & 10,723 & 152 & 85,041 \\
3. & Akibat Kecelakaan & & & \\
& - STBM & 9,237 & 98 & 8,412 \\
& - Cacat & 1,189 & 40 & 703 \\
& - Meninggal Dunia & 297 & 14 & 1,685 \\
\hline
\end{tabular}

Sumber:Kemnakertrans, Ditjen Pembinaan Hubungan Industrial

Atas dasar hal tersebut diatas maka diperlukan langkah dan penanggulangan terhadap kecelakan kerja tersebut.Kabupaten Kuningan dengan sentra kawasan industri perhotelan terletak di Sangkanhurip yang merupakan daya tarik wisata baik lokal maupun interlokal yang didukung oleh keadaan sumber daya alam yang mendukung terhadap kegiatan pariwisata.Kota sangkanhurip banyak berdiri hotel-hotel sebagai tempat peristirahatan tamu yang berkunjung baik dalam kegiatan liburan, rapat kerja, pesta pernikahan dan lain-lain. Setelah dilakukan survei terhadap hotel-hotel yang berada di kawasan Sangkanhurip, para manajer hotel menganggap penting variabel program keselamatan kerja dan kesehatan kerja, hal tersebut dibuktikan dengan adanya shift malam dan pengantaran barangbarang pelanggan. Adanya shift malam tentu saja dapat berpengaruh terhadap kondisi kesehatan para karyawannya, sehingga program kesehatan kerja perlu untuk diperhatikan secara seksama. Begitupun dengan keselamatan kerja, karena karyawan terlibat langsung dalam memberikan pelayanan kepada pelanggan, terutama dalam membantu para pelanggannya. Program keselamatan dna kesehatan kerja tersebut berguna untuk mengantisipasi menurunnya produktivitas yang diakibatkan sering absen karena sakit ataupun karena kecelakaan kerja. Beberapa hotel yang ada di kawasan Sangkanhurip Kabupaten Kuningan para karyawannya melakukan pengecekan kesehatan setiap 1 bulan sekalidalam upaya mencegah terjadinya penurunan kesehatan pada karyawan hotel di kawasan Sangkanhurip Kabupaten Kuningan. Dari uraian diatas, maka dalam penelitian ini peneliti tertarik untuk mengambil judul "Pengaruh Program Keselamatan dan Kesehatan Kerja terhadap Produktivitas Kerja Karyawan Hotel di Kawasan Sangkanhurip."

\section{LANDASAN TEORI}

Variabel dependent (variabel terikat) pada penelitian ini adalah produktivitas kerja, produktivitas merupakan perbandingan antara pengorbanan (input) dengan penghasilan (out put).Faktor-faktoryang mempengaruhi produktivitas, antara lain pendidikan dan latihan ketrampilan, gizi atau nutrisi, kesehatan, bakat atau bawaan, motivasi atau kemauan, kesempatan kerja, kesempatan manajemen dan kebijaksanaan pemerintah (Soeprihanto, 1996:7). Variabel independent, keselamatan kerja (X1) yang menunjukkan pada kondisi yang aman atau selamat dari penderitaan, kerusakan atau kerugian di tempat kerja. usaha untuk memberikan perlindungan keselamatan kerja pada karyawan dilakukan 2 cara (Soeprihanto, 1996:48) yaitu:

1. Usaha preventif atau mencegah

Preventif atau mencegah berarti mengendalikan atau menghambat sumbersumber bahaya yang terdapat di tempat kerja sehingga dapat mengurangi atau tidak menimbulkan bahaya bagi para karyawan.Langkah-langkah pencegahan itu dapat dibedakan, yaitu :

a) Subsitusi (mengganti alat/sarana yang kurang/tidak berbahaya)

b) Isolasi (memberi isolasi/alat pemisah terhadap sumber bahaya)

c) Pengendalian secara teknis terhadap sumber-sumber bahaya.

d) Pemakaian alat pelindung perorangan (eye protection, safety hat and cap, gas respirator, dust respirator, dan lain-lain).

e) Petunjuk dan peringatan ditempat kerja.

f) Latihan dan pendidikan keselamatan dan kesehatankerja. 
2. Usaha represif atau kuratif

Kegiatan yang bersifat kuratif berarti mengatasikejadian atau kecelakaan yang disebabkan oleh sumber-sumber bahaya yang terdapat di tempat kerja. Pada saat terjadi kecelakaan atau kejadian lainnya sangat dirasakan arti pentingnya persiapan baik fisik maupun mental para karyawan sebagai suatu kesatuan atau team kerja sama dalam rangka mengatasi dan menghadapinya. Selain itu terutama persiapan alat atau sarana lainnya yang secara langsung didukung oleh pimpinan organisasi perusahaan. Kesehatan kerja (X2) menunju:

a. Pemeriksaan kesehatan pada waktu karyawan pertama kali diterima bekerja.

b. Pemeriksaan keseluruhan para karyawan kunci (key personal) secara periodik.

c. Pemeriksaan kesehatan secara sukarela untuk semua karyawan secara periodik.

d. Tersedianya peralatan dan staff media yang cukup.

e. Pemberian perhatian yang sistematis yang preventif masalah ketegangan.

f. Pemeriksaan sistematis dan periodic terhadap persyaratan-persyaratan sanitasi yang baik.

Selain melindungi karyawan dari kemungkinan terkena penyakit atau keracunan, usaha menjaga kesehatan fisik juga perlu memperhatikan kemungkinan-kemungkinan karyawan memperoleh ketegangan atau tekanan selama mereka bekerja. Ketegangan ini tidak hanya menyerang tubuh manusia tetapi juga pikiran manusia. Kalau manusia tidak tahan terhadap ketegangan ini mereka akanmenjadi sakit. Karenanya usaha yang perlu dilakukanadalah untuk menghilangkan sumber ketegangan. Usaha-usaha untuk mencegah dan mengendalikan tekanan di dalam tempat kerja dapat dijalankan dengan cara (Ranupandojo dan Husnan, 2002:264) sebagai berikut:

a. Mencari sumber dari tekanan .

b. Mencari media yang menjadi alat penyebaran tekanan tersebut.

c. Memberi perawatan khusus pada karyawan yang menderita tekanan tersebut. Pada kondisi yang bebas dari gangguan fisik, mental, emosi atau rasa sakit yang disebabkan oleh lingkungan kerja.

\section{METODE PENELITIAN}

Metode yang digunakan dalam penelitian ini adalah kuantitatif, alat ukur penelitian ini berupa kuesioner, Data yang diperoleh berupa jawaban dari karyawan terhadap pertanyaan atau butirbutir yang diajukan. Butir-butir yang baik (J.Supranto, 2001:80) adalah sebagai berikut:

1. Butir-butir harus relevan atau terkait dengan apa yang diukur.

2. Butir-butir harus ringkas.

3. Butir-butir tidak membingungkan.

4. Butir-butir yang bagus harus memuat satu pemikiran.

Setelah menentukan pertanyaan atau butirbutirlangkah selanjutnya adalah pembentukan skala akan memilih satu format jawaban untuk daftar pertanyaan. Di dalam penelitian ini peneliti menggunakan format tipe linkert karena menurut J. Supranto dalam Lissita dan Green tipe likert tercermin dalam keragaman skor (variability of scorer) sebagai akibat penggunaan skala berkisar antara 1 sampai dengan 5 , dari segi pandangan statistik, Skala dengan lima tingkatan (dari 1 sampai 5) lebih tinggi keandalannya dari skala dua tingkatan yaitu ya atau tidak. Teknik pengambilan sampel pada penelitian ini menggunakan teknik random samplingyaitu semua anggota populasi memperoleh kesempatan yang sama untuk dipilih secara rondom/acak sebagai bagian dari sampel dalampenelitian. Sumber data pada penelitian ini bersumber dari data primer dan data sekunder. Data primer dihasilkan dari kuesioner yang disebarkan pada karyawan hotel di kawasan Sangkanhurip Kabupaten Kuningan, sedangkan data sekunder adalah data dokumentasi perusahaan, buku-buku referensi, dan informasi lain yang berhubungan dengan penelitian.

Teknik analisis yang digunakan pada penelitian ini menggunakan analisis regresi linier berganda.Sebelum dilakukan uji validitas dan reliabilitas terlebih dahulu dilakukan uji validitas dan reliabilitas data.Uji validitas dimaksudkan untuk mengetahui ketepatan dari alat ukur yang digunakan, sementara uji reliabilitas data dimaksudkan untuk mengetahui tingkat kehandalan dari alat ukur yang telah digunakan.Analisis regresi linier berganda dimaksudkan untuk menganalisis kontribusi pengaruh dan uji hipotesis.Persamaan regresi berganda mengandung makna bahwa dalam suatu persamaan regresi terdapat satu variabel 
dependent dan lebih dari satu variabel independent (Algifari, 2000:62). Secara umum model regresi berganda dirumuskan sebagai berikut:

$\mathrm{Y}=\mathrm{a}+\mathrm{b} 1 \mathrm{X} 1+\mathrm{b} 2 \mathrm{X} 2$

Keterangan :

Y : Produktivitas Kerja Karyawan

a : konstanta

X1 : program Keselamatan Kerja

X2 : program Kesehatan Kerja

b1 : Koefisien regresi Faktor Keselamatan Kerja

b2 : Koefisien regresi Faktor Kesehatan Kerja

Untuk mendapat kepastian dari persamaan regresi tersebut, tiap-tiap variabel diadakan tes hipotesis dengan menggunakan variabel independent (Keselamatan kerja dan Kesehatan kerja) berpengaruh terhadap variabel dependent (Produktivitas kerja), oleh karenanya diadakan Uji Signifikan Statistik.

1. Uji F

Pengujian ini dilakukan untuk mengetahui apakah semua variabel independen berpengaruh terhadap variabel dependen.Langkah-langkah sebagai berikut :

a. Menentukan hipotesa nihil dan hipotesa alternatif.

1) Ho : $\beta=0$ Secara bersama-sama program keselamatan dan program kesehatan kerja tidak berpengaruh terhadap produktivitas kerja karyawan.

2) $\mathrm{H} 1: \beta \nexists$ Secara bersama-sama program keselamatan dan program kesehatan kerja berpengaruh terhadap produktivitas kerja karyawan.

b. Level of significance $=5 \%$

c. Kriteria pengujian

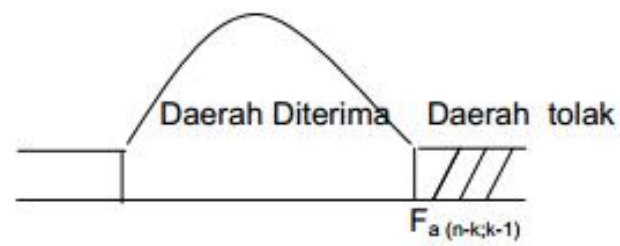

Ho diterima apabila $\mathrm{F} \& \mathrm{Fa}(\mathrm{n}-\mathrm{k} ; \mathrm{k}-1)$

Ho ditolak apabila F > Fa (n-k;k-1) d. Perhitungan nilai $\mathrm{F}$

$\mathrm{F}=\frac{\text { Variance between means }}{\text { Variance within group }}$

$$
F=\frac{j=\sum_{i}^{k} \frac{T^{2}}{n j}-\frac{T^{2}}{n} / k-1}{\sum_{i=1}^{n} \sum_{j=1}^{k} X_{i j}^{2}-\sum_{j=1}^{k} \frac{T^{2} j}{j=1} / n-k}
$$

Keterangan

Fhitung : nilai Fhitung

$\mathrm{N}$ : Banyaknya individu sampling

$\mathrm{K} \quad$ : banyaknya sampling el

$\mathrm{Tj} \quad$ : Jumlah semua individu dalam sampel $\mathrm{j}$

Xij : individu ke-1 di sample ke-j

e. Kesimpulan

Dengan membandingkan Fhitung dengan Ftabel dapat diketahui hubungan program keselamatan kerja dan kesehatan kerja dengan produktivitas kerja.

2. Uji parsial

Uji parsial ini digunakan untuk mengetahuipengaruh program keselamatan kerja dan kesehatan kerja dengan produktivitas kerja secara individual dan digunakan untuk menguji dominasi pengaruh variabel program kesehatan karyawan .

Langkah-langkah sebagai berikut :

a Menentukan hipotesa nihil dan hipotesa alternatif.

$\checkmark$ Ho : $\beta=0$ Secara individu program keselamatan dan program kesehatan kerja tidak berpengaruh terhadap produktivitas kerja karyawan.

$\checkmark$ H1 : $\beta \neq$ Secara individu program keselamatan dan program kesehatan kerja berpengaruh terhadap produktivitas kerja karyawan.

b. Level of significance $=5 \%$

c. Kriteria pengujian

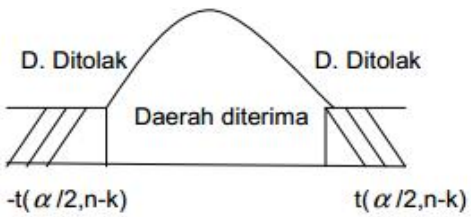

Ho diterima apabila $-\mathrm{t}(\alpha / 2, \mathrm{n}-\mathrm{k})<\mathrm{t}_{\text {nit }}<(\alpha / 2, \mathrm{n}-\mathrm{k})$

Ho ditolak apabila $\mathrm{t}_{\mathrm{n} \text { t }}<-\mathrm{t}(\alpha / 2, \mathrm{n}-\mathrm{k})$ atau $\mathrm{t}_{\text {hit }}>(\alpha / 2, \mathrm{n}-\mathrm{k})$ 
d. Menentukan nilai t hitdengan menggunakan rumus:

$$
t=\frac{\beta i}{\int e(\beta i)}
$$

Keterangan

i $\beta$ : Koefisien regresi variabel ke i

e $\int$ : Standart error atau kesalahan

e. Kesimpulan

Dengan membandingkan $t$ hitung dengan $t$ tabel dapat diketahui hubungan program keselamatan kerja dan kesehatan kerja dengan produktivitas kerja

\section{Analisis Koefisien Determinasi $\left(\mathrm{r}^{2}\right)$}

Koefisien determinasi adalah salah satu nilai statistik yang dapat digunakan untuk mengetahui apakah ada hubungan pengaruh antara dua variabel.Nilai koefisien determinasi menunjukkan persentase variasi nilai variabel dependen yang dapat dijelaskan oleh persamaan regresi yang dihasilkan.Besarnya persentase pengaruh semua variabel independent terhadap nilai variabel dependen dapat diketahui dari besarnya koefisien determinasi $\left(\mathrm{r}^{2}\right)$ persamaan regresi.

Besarnya koefisien determinasi adalah 0 sampai dengan 1 , semakin mendekati 0 besarnya koefisien determinasi $\left(\mathrm{r}^{2}\right)$ suatu persamaan regresi, semakin kecil pula pengaruh semua variabel independent terhadap nilai variabel dependent. Sebaliknya, Semakin mendekati 1 besarnya koefisien determinasi $\left(\mathrm{r}^{2}\right)$ suatu persamaan regresi, Semakin besar pula pengaruh semua variabel independent terhadap variabel dependent.

\section{HASIL PENELITIAN}

\section{A. Analisis Validitas}

Validitas adalah suatu ukuran yang menunjukkan tingkat kehandalan atau kesahihan sesuatu instrument. Suatu instrumentyang valid atau sahih mempunyai validitas tinggi. Instrumen dikatakan valid apabila mampu mengukur apa yang diinginkan, mampu mengungkap datadari variabel yang diteliti secara tepat. Tinggi rendahnya validitas instumen menunjukkan sejauh mana data yang terkumpul tidak menyimpang dari gambaran tentang validitas yang dimaksud (Suharsimi Arikunto, 148:1998).Hasil analisis validitas program SPSS 17.00 ditunjukkan dengan membandingkan $r$ hasil (hitung) dengan nilai $r$ tabel. Sedangkan nilai $\mathrm{r}$ hasil dalam Corrected Item Total Correlation. Kemudian untuk mengambil $r$ hasil $>\mathrm{r}$ tabel, maka butir atau variabel yang diteliti adalah valid.Uji validitas ini di distribusikan kepada 30 responden karyawan manajemen hotel di kawasan di kawasan Sangkanhurip Kabupaten Kuningan.Dari hasil perhitungan dengan menggunakan SPSS 17.00 kuesioner pada variabel keselamatan kerja (X1), kesehatan kerja(X2) dan produktivitas kerja (Y) adalah valid karena nilai $r$ hitung $>\mathrm{r}$ tabel. Berikut ini hasil SPSS 17.00 uji validitas dan reliablitas.

Tabel 2 Hasil Uji Validitas Butir Keselamatan Kerja

\begin{tabular}{|c|c|c|c|c|c|}
\hline \multirow{2}{*}{$\begin{array}{c}\text { Peranyzan } \\
\text { Butr }\end{array}$} & \multirow{2}{*}{ Niai r Hitung } & \multicolumn{3}{|c|}{ Nlai r Tabel } & \multirow{2}{*}{ Status } \\
\cline { 3 - 5 } & & Df $(\mathrm{n}-2)$ & $\alpha$ & r tabe & \\
\hline 1 &, 5671 & 28 & $5 \%$ & 0.374 & Valic \\
\hline 2 &, 7201 & 28 & $5 \%$ & 0.374 & Valic \\
\hline 3 &, 7478 & 28 & $5 \%$ & 0.374 & Valic \\
\hline 4 &, 6934 & 28 & $5 \%$ & 0.374 & Valic \\
\hline 5 &, 7478 & 28 & $5 \%$ & 0.374 & Valic \\
\hline
\end{tabular}

Sumber : Data diolah

Hasil uji validitas butir keselamatan kerja dari lima butir pertanyaan yang diambil dari 30 respoden menyatakan bahwa $r$ hitung $>r$ tabel maka pernyataan tersebut Valid.

Tabel 3 Hasil Uji Validitas ButirKesehatan Kerja

\begin{tabular}{|c|c|cc|c|c|}
\hline $\begin{array}{c}\text { Pertaryaan } \\
\text { Buti }\end{array}$ & Niai r Hitung & \multicolumn{3}{|c|}{ Nilair Tabel } & \multirow{2}{*}{ Status } \\
\cline { 3 - 5 } & & Df(n-2) & $\alpha$ & $\mathrm{r}$ tabel & \\
\hline 1 &, 7879 & 28 & $5 \%$ & 0.374 & Valid \\
\hline 2 &, 9265 & 28 & $5 \%$ & 0.374 & Valid \\
\hline 3 &, 9388 & 28 & $5 \%$ & 0.374 & Valid \\
\hline 4 &, 9018 & 28 & $5 \%$ & 0.374 & Valid \\
\hline 5 &, 8991 & 28 & $5 \%$ & 0.374 & Valid \\
\hline
\end{tabular}

Sumber : Data diolah

Hasil uji validitas butir kesehatan kerja dari limabutir pertanyaan yang diambil dari 30 respoden menyatakan bahwa $r$ hitung $>r$ tabel maka pernyataan tersebut Valid. 
Tabel 4 Hasil Uji Validitas ButirProduktivitas Kerja

\begin{tabular}{|c|c|c|c|cc|}
\hline $\begin{array}{c}\text { Pertaryaan } \\
\text { Buti }\end{array}$ & Nilai r Hitung & \multicolumn{3}{|c|}{ Nilai r Tabel } & Status \\
\cline { 3 - 5 } & & Df $(n-2)$ & $\alpha$ & r tabel & \\
\hline 1 & 6083 & 28 & $5 \%$ & 0.374 & Valid \\
\hline 2 & 8645 & 28 & $5 \%$ & 0.374 & Valid \\
\hline 3 & 8545 & 28 & $5 \%$ & 0.374 & Valid \\
\hline 4 & 4052 & 28 & $5 \%$ & 0.374 & Valid \\
\hline 5 & 8945 & 28 & $5 \%$ & 0.374 & Valid \\
\hline
\end{tabular}

Sumber : Data diolah

Hasil uji validitas butir produktivitas kerja dari lima butir pertanyaan yang diambil dari 30 respoden menyatakan bahwa $r$ hitung $>r$ tabel maka pernyataan tersebut Valid.

\section{B. Analisis Reliabilitas}

Reliabilitas menunjuk pada suatu pengertian bahwa sesuatu instrument cukup dapat dipercaya untuk digunakan sebagai alat pengumpul data karena intrumen tersebut sudah baik. Instrumen yang baik tidak akan bersifat tendensius mengarahkan responden untuk memilih jawabanjawabantertentu. Instrumen yang sudah dapat dipercaya, yang realibel akan menghasilkan data yang dapat dipercaya juga. Apabila datanya memang benar sesuai dengan kenyataannya, maka berapa kalipun diambil tetap akan sama. Reliabilitas menunjuk pada tingkat keterandalan sesuatu. Reliabel artinya, dapat dipercaya, jadi dapat diandalkan (Suharsimi Arikunto, 1998:154).r alpha program SPSS 10.01 ditunjukkan oleh besarnya nilai alpha $(\alpha)$. Pengambilan keputusan reliability suatu variabel ditentukan dengan asumsi apabila nilai $\mathrm{r}$ alpha > nilai $r$ tabel, maka butir atau variabel yang diteliti adalah reliabel.

Hasil Uji Reliabilitas dari perhitungan SPSS 17.00 menyatakan bahwa faktor keselamatan kerja realibel hal tersebut terbukti bahwa $r$ alpha $>\mathrm{r}$ tabel yaitu 0,8691>0,374. Program kesehatan kerja juga reliabel yaitu 0,9607> 0.374. Dan untuk produktivitas kerja juga reliabel yaitu $0,8816>0,374$. Untuk lebih jelasnya berikut ini tabel hasil perhitungan SPSS 17.00:
Tabel 5 Hasil Uji Reliabilitas Butir

\begin{tabular}{|c|cc|c|cc|}
\hline Pertanyaan & Nila r Hitung & \multicolumn{3}{|c}{ Nlair Tabel } & Status \\
\cline { 2 - 5 } Faktor & & Df(n-2) & $\alpha$ & r tabel & \\
\hline $\mathrm{X} 1$ & 8691 & 28 & $5 \%$ & 0.374 & Reliabel \\
\hline $\mathrm{X} 2$ & 9607 & 28 & $5 \%$ & 0.374 & Reliabel \\
\hline $\mathrm{Y}$ & 8816 & 28 & $5 \%$ & 0.374 & Reliabel \\
\hline
\end{tabular}

Sumber : Data diolah

\section{Analisis Regresi}

Persamaan regresi berganda mengandung makna bahwa dalam suatu persamaan regresi terdapat satu variabel dependent dan lebih dari satu variabel independent (Algifari, 2000:62). Hasil regresi yang diperoleh dari SPSS 17.00. yaitu:

$\mathrm{Y}=0,151+0,208 \mathrm{X} 1+0,747 \mathrm{X} 2$

Berdasarkan hasil uji regresi, maka dapat diinterprestasikan sebagai berikut:

a. Konstanta sebesar 0,151

Artinya bahwa jika tidak menerapkan program keselamatan kerja (X1) dan kesehatan kerja (X2), maka tingkat produktivitas kerja sebesar 0,151 .

b. Koefisien regresi 0,208

Artinya bahwa jika pihak manajemen hotel di kawasan di kawasan Sangkanhurip Kabupaten Kuninganmenaikkan program keselamatan kerja (X1) kepada para karyawannya maka akan berpengaruh terhadap produktivitas kerja karyawan sebesar 0,208.

c. Koefisien regresi 0,747

Artinya bahwa jika manajemen hotel di kawasan di kawasan Sangkanhurip Kabupaten Kuninganmenaikkan program kesehatan kerja (X2) kepada para karyawannya maka akan berpengaruh terhadap produktivitas kerja karyawan sebesar 0,747 .

\section{Uji Statisitik Uji F}

Pengujian ini dilakukan untuk mengetahui apakah semua variabel independen berpengaruh terhadap variabel dependen.Langkah-langkah sebagai berikut:

a. Menentukan hipotesa nihil dan hipotesa alternatif.

- Ho : $\beta=0$ Secara bersama-sama program keselamatan dan program kesehatan kerja tidak berpengaruh terhadap produktivitas kerja karyawan.

- $\mathrm{H} 1: \beta \neq$ Secara bersama-sama program keselamatan dan program kesehatan kerja 
berpengaruh terhadap produktivitas kerja karyawan.

b. Level of significance $=5 \%$

c. Pengujian Hipotesis

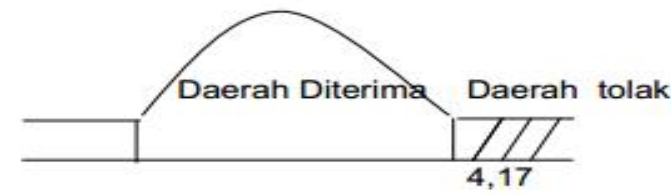

Ho diterima apabila $\mathrm{F} \quad \mathrm{Fa}(\mathrm{n}-\mathrm{k} ; \mathrm{k}-1)$

Ho ditolak apabila $\mathrm{F}>\mathrm{Fa}(\mathrm{n}-\mathrm{k} ; \mathrm{k}-1)$

F tabel : $\alpha(\mathrm{n}-\mathrm{k} ; \mathrm{k}-1)$

$$
\begin{aligned}
& : 0,05(30-2 ; 2-1) \\
& : 0,05(28 ; 1) \\
& : 4,17
\end{aligned}
$$

d. Perhitungan nilai $F$

F hitung di peroleh dari hasil perhitungan SPSS pada ANOVA, pada penelitian program keselamatan kerja dan kesehatan kerja dengan produktivitas kerja $\mathrm{F}$ hitungnya adalah 54,557.

e. Kesimpulan

Nilai F hitung 54,557 lebih besar dari F tabel 4,17 maka Ho ditolak berarti bahwa ada pengaruh yang signifikan dari program keselamatan kerja (X1) dan kesehatan kerja (X2) secara bersama-sama terhadap produktivitas kerja karyawan.

Dengan demikian dapat disimpulkan bahwa ada hubungan antara program keselamatan dan kesehatan kerja dengan produktivitas kerja karyawan hotel di kawasan di kawasan Sangkanhurip Kabupaten Kuningan.

\section{E. Uji Statisitik Uji T}

Uji parsial ini digunakan untuk mengetahui pengaruh program keselamatan kerja dan kesehatan kerja dengan produktivitas kerja secara individual dan digunakan untuk menguji dominasi pengaruh variabel program kesehatan karyawan.

Langkah-langkah sebagai berikut:

a. Menentukan hipotesa nihil dan hipotesa alternatif.

- Ho : $\beta=0$ Secara individu program keselamatan dan program kesehatan kerja tidak berpengaruh terhadap produktivitas kerja karyawan.

- $\mathrm{H} 1: \beta \nRightarrow$ Secara individu program keselamatan dan programkesehatan kerja berpengaruh terhadap produktivitas kerja karyawan. c. Pengujian Hipotesis

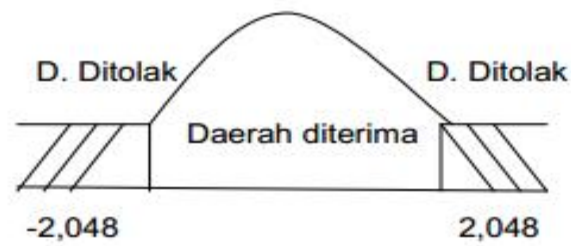

Ho diterima apabila $-\mathrm{t}(\alpha / 2, \mathrm{n}-\mathrm{k})<\mathrm{t}$

hit $<(\alpha / 2, \mathrm{n}-\mathrm{k})$

Ho ditolak apabila $\mathrm{t}$ hit $<-\mathrm{t}(\alpha / 2, \mathrm{n}-\mathrm{k})$ atau $\mathrm{t}$ hit $>$ ( $\alpha / 2, \mathrm{n}-\mathrm{k})$

Nilai T tabel $\quad:(\alpha / 2 ; \mathrm{n}-\mathrm{k})$

$$
\begin{aligned}
& :(0,05 / 2 ; 30-2) \\
& :(0,025 ; 28) \\
& : 2,048
\end{aligned}
$$

d. Perhitungan nilai $\mathrm{T}$ hitung

$\mathrm{T}$ hitung diperoleh dari hasil perhitungan SPSS 10.01 pada Coefficients, untuk program keselamatan kerja sebesar 6,642 dan kesehatan kerja sebesar 2,845

e. Kesimpulan

Nilai $\mathrm{t}$ hitung untuk program keselamatan kerja (X1) 6,642 > t tabel 2,048 maka Ho ditolak, berarti keselamatan kerja berpengaruh secara signifikan terhadap produktivitas kerja karyawan.Nilai $\mathrm{t}$ hitung untuk program kesehatan kerja (X2) 2,845 > t tabel 2,048 maka Ho ditolak, berarti kesehatan kerja berpengaruh secara signifikan terhadap produktivitas kerja karyawan.

Dari hasil perhitungan menggunakan SPSS 17.00 dapat diketahui nilai keselamatan kerja sebesar 6,642 adalah lebih besar dari kesehatan kerja yaitu 2,845 maka dapat dikatakan bahwa keselamatan kerja (X1) memiliki pengaruh yang paling besar. Dengan demikian dapat disimpulkan bahwa ada hubungan antara program keselamatan kerja dan kesehatan kerja dengan produktivitas kerja hotel di kawasan di kawasan Sangkanhurip Kabupaten Kuningan, yang lebih berpengaruh dari kedua variabel independent tersebut adalah program keselamatan kerja dan berarti hipotesa tersebut adalah benar.

\section{F. Analisis Korelasi antara keselamatan kerja $\left(X_{1}\right)$ dengan kesehatan kerja $\left(X_{2}\right)$ \\ Analisis korelasi dimaksudkan untuk} mengetahui derajat hubungan antara variabel independen dengan variabel independen lainnya. Adapun besarnya derajat hubungan mengacu pada pendapat Sudjana (2002), sebagai berikut :

b. Level of significance $=5 \%$

Computer Science | Industrial Engineering | Mechanic Engineering | Civil Engineering 
Tabel 6 Tabel Korelasi

\begin{tabular}{|l|l|}
\hline \multicolumn{1}{|c|}{ Correlation $(\mathbf{r})$} & \multicolumn{1}{|c|}{ Indication } \\
\hline Between, \pm 80 to 1,00 & High correlation (Sangat tinggi) \\
Between, \pm 60 to, 79 & Moderately high correlation \\
Between, \pm 40 to, 59 & (Tinggi) \\
Between, \pm 20 to, 39 & $\begin{array}{l}\text { Moderately correlation } \\
\text { Between } \pm, 01 \text { to }, 19\end{array}$ \\
& (Sedang) \\
& $\begin{array}{l}\text { Low correlation (Rendah) } \\
\text { Negligible correlation ( Sangat } \\
\text { rendah) }\end{array}$ \\
\hline
\end{tabular}

Sumber: Sudjana, 2003

Adapun hasil analisis korelasi dengan menggunakan perhitungan statistik yang dibantu dengan program SPSS versi 17.00 , sebagai berikut:

Tabel 7 Korelasi antara $X_{1}$ dengan $X_{2}$

\begin{tabular}{|ll|r|r|}
\hline & & \multicolumn{1}{|c|}{$\mathrm{X}_{1}$} & \multicolumn{1}{|c|}{$\mathrm{X}_{2}$} \\
\hline $\mathrm{X}_{1}$ & Pearson Correlation & 1 & $.647^{* *}$ \\
& Sig. (2-tailed) & & .000 \\
& $\mathrm{~N}$ & 30 & 30 \\
\hline $\mathrm{X}_{2}$ & Pearson Correlation & $.647^{* *}$ & 1 \\
& Sig. (2-tailed) & .000 & \\
& $\mathrm{~N}$ & 30 & 30 \\
\hline
\end{tabular}

Hubungan variabel antara keselamatan kerja $\left(\mathrm{X}_{1}\right)$, dengan kesehatan kerja $\left(\mathrm{X}_{2}\right)$, diperoleh nilai koefisien korelasi yang sebesar 0,647. Dengan demikian, dapat dikatakan bahwa hubungan kedua variabel tersebut di atas mempunyai hubungan yang positif dengan kriteria keeratan hubungan Moderately high correlation ( Tinggi ).

\section{G. Analisis Koefisien Determinasi $\left(\mathbf{r}^{2}\right)$}

Koefisien determinasi adalah salah satu nilai statistik yang dapat digunakan untuk mengetahui apakah ada hubungan pengaruh antara dua variabel.Nilai koefisien determinasi menunjukkan persentase variasi nilai variabel dependen yang dapat dijelaskan oleh persamaan regresi yang dihasilkan.Besarnya persentase pengaruh semua variabel independent terhadap nilai variabel dependen dapat diketahui dari besarnya koefisien determinasi $\left(r^{2}\right)$ persamaan regresi.Angka koefisien determinasi dilihat dari hasil perhitungan SPSS 17.00.

Tabel 4.7 Model Summaryb

\section{Model Summary}

\begin{tabular}{|l|c|c|c|c|}
\hline $\begin{array}{l}\text { Mode } \\
\mathrm{l}\end{array}$ & $\mathrm{R}$ & $\begin{array}{c}\mathrm{R} \\
\text { Square }\end{array}$ & $\begin{array}{c}\text { Adjusted R } \\
\text { Square }\end{array}$ & $\begin{array}{c}\text { Std. Error of } \\
\text { the Estimate }\end{array}$ \\
\hline
\end{tabular}

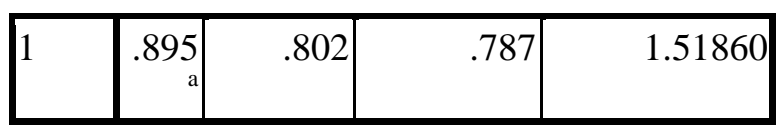

a. Predictors: (Constant), X2, X1

Sumber: Data diolah

Koefisien Determinasi ditunjukkan pada angka $\mathrm{R}$ square adalah 0,802 menunjukkan bahwa $80,2 \%$ variasi variabel produktivitas kerja dapat dijelaskan oleh variabel keselamatan kerja (X1) dan kesehatan kerja (X2) dan sisanya sebesar 0,198 atau 19,7\% lainnya dijelaskan oleh variabel-variabel lain. Jadi pengaruh program keselamatan dan kesehatan kerja terhadap produktivitas kerja karyawan hotel di kawasan di kawasan Sangkanhurip Kabupaten Kuningansebesar 80,2\%.

\section{PENUTUP}

Sesuai dengan tujuan yang telah dirumuskan dalam penelitian ini, maka hasil analisis yang telah dilakukan, secara ringkasdapat diuraikan sebagai berikut:

1. Variabel program keselamatan kerja dan kesehatankerja berpengaruh secara bersamasama terhadap variabel dependen. Hal ini terbukti dengan hasil perhitungan SPSS yang menyatakan bahwa nilai $\mathrm{F}$ hitung 54,557 yaitu lebih besar dari nilai $\mathrm{F}$ tabel 4,17 maka Ho ditolak berarti bahwa ada pengaruh yang signifikan dari program keselamatan kerja (X1) dan kesehatan kerja (X2) secara bersama-sama terhadap produktivitas kerja karyawan.

2. Variabel program keselamatan kerja dan kesehatan kerja berpengaruh secara individual terhadap produktivitas kerja karyawan. Nilai $\mathrm{t}$ hitung untuk program keselamatan kerja (X1) 6,642> t tabel 2,048 maka Ho ditolak, berarti keselamatan kerja berpengaruh secara signifikan terhadap produktivitas kerja karyawan. Nilai $\mathrm{t}$ hitung untuk program kesehatan kerja (X2) 2,845> t tabel 2,048 maka Ho ditolak, berarti kesehatan kerja berpengaruh secara signifikan terhadap produktivitas kerja karyawan. Dari hasil perhitungan menggunakan SPSS 17.00 dapat diketahui nilai keselamatan kerja sebesar 6,642 adalah lebih besar dari kesehatan kerja yaitu 2,845 maka dapatdikatakan bahwa keselamatan kerja (X1) memiliki pengaruh yang paling besar.

Berdasarkan kesempulan diatas, maka penelitimemberikan saran-saran sebagai berikut: 
1. Program keselamatan dan kesehatan kerja harus tetap dipertahankan, bahkan ditingkatkan. Hal ini dikarenakan berdasarkan penelitian yang telah dilakukan kedua program tersebut secara signifikan berpengaruh terhadap produktivitas.

2. Mengefektifkan program keselamatan dan kesehatankerja karyawan yang bertujuan untuk meningkatkan produktivitas kerja yang lebih baik, maka kekuatan perusahaan yang terletak pada sumber daya manusianya harus lebih diprioritaskan, yang dimulai dari pengadaaan tenaga kerja, peningkatan sumber daya manusia, sampai kepada perhatian aspek kesehatan, baik yang bersifat fisik maupun psikologis karyawan itu sendiri.

3. Untuk Meningkatkan output yang dihasilkan oleh perusahaan maka produktivitas perlu ditingkatkan dengan mempekerjakan tenaga kerja yang benar-benar trampil dan berkualitas kerena hal ini dapat mengurangi terjadinya kecelakaan selama bekerja.

\section{DAFTAR PUSTAKA}

Algifari, Analisis Regresi, BPFE Yogyakarta, 2000.

Arikunto Suharsimi, Prosedur Penelitian suatu Pendekatan Praktek, Rineka Cipta Jakarta,1998.

Djarwanto \& Subagyo Pangestu, Statistik Induktif, BPFE Yogyakarta,1993. Gujarati Damodar, Ekometrika Dasar, edisi empat.

Handoko Hani T, Manajemen Personalia dan Sumber Daya Manusia, BPFE Yogyakarta,2001.

Heidjrachman \& Husnan Suad, Manajemen Personalia, BPFE, Yogyakarta,2002.

I Cahyono Bambang Tri, Manajemen Sumber Daya Manusia, IPWI Jakarta,1996.

Mangkunegara Prabu Anwar A.A, Manajemen Sumber Daya Manusia Perusahaan, PT Remaja Rosdakarya Bandung, 2001.

Nasution S, Metode Research, Bumi Aksara Jakarta, 2003.

Singarimbun Masri \& Effendi Gofian, Metodologi Penelitian Survai, Pustaka LP3ES Jakarta, 1989.

Soeprihanto John, Manajemen Personalia, BPFE Yogyakarta,1996.

Computer Science | Industrial Engineering | Mechanic Engineering |Civil Engineering
Soeratno \& Arsyad Lincolin, Metodologi Penelitian, UPP AMP YKPN Yogyakarta, 1999.

Suma'mur, Keselamatan Kerja dan Pencegahan Kecelakaan, CV Haji Masagung Jakarta,1993.

Supranto J, Pengukuran Tingkat Kepuasan Pelanggan, Rineka Cipta Jakarta,2001.

Tulus Agus, Manajemen Sumber Daya Manusia, PT Gramedia Pustaka Utama Jakarta,1992.

Wahana Komputer Semarang, 10 Model Penelitian dan Pengolahannya dengan SPSS 17.00, Penerebit Andi Yogyakarta,1998. 